\title{
Effect of Processing Methods on the Nutritional Value of Canavalia ensiformis Jack Bean Seed Meal
}

Michael KG*, Sogbesan OA and Onyia LU

Department of Fisheries, Modibbo Adama University of Technology Yola, PMB 2076, Adamawa State, Nigeria

\begin{abstract}
The present study was undertaken to analyze the effect of various processing methods. Raw, Boiled, Toasted, Soaked and Fermented methods were applied on Canavalia ensiformis Jack bean seed meals to determine their nutritional compositions. The applied methods were found to improve the protein content (30\%-36.60\%), lipid $(5.85 \%-9.23 \%)$, fiber $(3.25 \%-6.35 \%)$, ash (3.5\%-5.32\%), Nitrogen-free extract (38.79\%-46.21\%). There was an increase in the mineral composition with processing methods; potassium, calcium and sodium were the most abundant macro minerals in Canavalia seed meal. There was also an increase in the essential amino acids of the processed minerals. Methionine content was increased due to fermentation $(2.12 \mathrm{~g} / 100 \mathrm{~g})$ as compared to the raw $(0.81 \mathrm{~g} / 100 \mathrm{~g})$. Vitamins A (1425.32-6124.56 IU/100 g), B1 (0.15-0.32 mg/100 g), B3 $(0.06-0.21 \mathrm{mg} / 100 \mathrm{~g}), B 6(0.03-0.19 \mathrm{mg} / 100 \mathrm{~g}), C(7.54-25.65 \mathrm{mg} / 100 \mathrm{~g})$ and $\mathrm{D}(0.36-0.53 \mathrm{mg} / 100 \mathrm{~g})$. There was a reduction in vitamins content from boiled and toasted methods. Fatty acids: Capric $(0.002-0.0035 \mathrm{~g} / 100 \mathrm{~g})$, Lauric $(0.003-0.004 \mathrm{~g} / 100$ g), Myristic (0.004-0.006 g/100 g), Palmitic (0.015-0.023 g/100 g), Stearic (0.013-0.019 g/100 g), Oleic (0.016-0.021 g/100 $\mathrm{g})$, linoleic $(0.024-0.039 \mathrm{~g} / 100 \mathrm{~g})$ and Arachidic $(0.003-0.006 \mathrm{~g} / 100 \mathrm{~g})$. The toasted and fermented method gave the bestprocessed methods. Knowledge gathering and exploration of nutritionally balanced unconventional legumes would enhance food and nutritional security.
\end{abstract}

Keywords: Unconventional legumes; Canavalia ensiformis Processing; Nutrients

\section{Introduction}

Legumes have been recognized to be the second most valuable plant source for human, animal nutrition and the third largest family among flowering plants, consisting of approximately 650 genera and 20000 species [1,2]. Kalidass and Mohan [3] reported that legume seeds are important sources of nutrients and can serve as high-quality dietary protein to meet the nutrient requirements of fishes [4,5]. These seeds have an average of twice protein content as in cereals and the nutritive values of the proteins in legumes are usually higher [6]. The unconventional legumes have tremendous potential for commercial exploitation but remain ignored, form a good scope in this context [7]. Switching by most of the world's population to a protein-rich vegetarianbased diet from animal-based protein has created unwarranted scarcity to plant protein resources. In this regard, legumes have been highlighted as an effective substitute for animal protein [8]. Considering the above, it becomes imperative for nutritionists to search for cheap, reliable, and safe plant-based resources to accomplish the demand for protein-rich feed.

Jack bean of the genus Canavalia comprises forty-eight species of these underutilized legumes. They are indigenous to tropical regions where they are widely distributed [9]. They are rarely eaten by humans and yield about 2.5 tons $\mathrm{ha}^{-1}$ when grown under optimal agronomic conditions [10]. The present study has been designed to explore the effect of various processing methods on the nutritional values of Canavalia ensiformis seeds meal.

\section{Materials and Methods}

\section{Seeds collection and identification}

Matured Canavalia ensiformis seeds were collected from Girei and surroundings. They were identified by plant Taxonomist in Forestry and Wildlife Department of Modibbo Adama University of Technology, Yola (MAUTECH) Adamawa State. Adamawa State is located on latitude $9.14^{\circ} \mathrm{N}$, longitude $12.38^{\circ} \mathrm{E}$ and altitude of $185.9 \mathrm{~m}$ [11].

\section{Preparation of the legume seeds and processing}

Canavalia ensiformis seeds were cracked open manually to remove the coats. The seeds were clean of dirt by hand picking and winnowed. The processing was done according to Doss et al. [12].

1. Raw seeds were milled and tag raw seed meal (RSM)

2. Raw seeds were soaked in tap water to the ratio of $1: 3$ for 72 hours, oven dried at $50^{\circ} \mathrm{C}$ to constant weight then milled and tag soaked seed meal (SSM)

3. Raw seeds were boiled for 30 minutes, oven dried at $50^{\circ} \mathrm{C}$ to constant weight then milled and tag boiled seed meal (BSM)

4. Raw seeds were toasted at $70^{\circ} \mathrm{C}$ using electric hot plate until seeds turn brown in color then milled and tag Toasted Seed Meal (TSM)

5. Raw seeds were moistened with water, kept in a container with the cover in a dark place to ferment for 72 hours under laboratory condition, oven dried at $50^{\circ} \mathrm{C}$ then milled and tag Fermented Seed Meal (FSM)

\section{Laboratory analysis}

The samples were packaged and send to Animal Nutrition laboratory, Adamawa State University Mubi for the analysis. Proximate, Minerals, Essential amino acids, vitamins, and fatty acids were determined using standard methods of AOAC [13]

*Corresponding author: Michael KG, Department of Fisheries, Modibbo Adama University of Technology Yola, P.M.B. 2076, Adamawa State, Nigeria, Tel: 08063692508; E-mail: keccybaby1258@gmail.com

Received September 11, 2018; Accepted November 08, 2018; Published November 12, 2018

Citation: Michael KG, Sogbesan OA, Onyia LU (2018) Effect of Processing Methods on the Nutritional Value of Canavalia ensiformis Jack Bean Seed Meal. J Food Process Technol 9: 766. doi: 10.4172/2157-7110.1000766

Copyright: ( 2018 Michael KG, et al. This is an open-access article distributed under the terms of the Creative Commons Attribution License, which permits unrestricted use, distribution, and reproduction in any medium, provided the original author and source are credited. 
Citation: Michael KG, Sogbesan OA, Onyia LU (2018) Effect of Processing Methods on the Nutritional Value of Canavalia ensiformis Jack Bean Seed Meal. J Food Process Technol 9: 766. doi: 10.4172/2157-7110.1000766

Page 2 of 5

\section{Statistical analysis}

Data collected were recorded as a Mean \pm standard deviation, Subjected to one- way ANOVA.

\section{Results}

Table 1 shows Proximate and mineral compositions of the raw and processed seeds of C. ensiformis. The processed seeds had the highest values of protein, crude lipid, and ash while the raw seeds had the highest Nitrogen-free extract (carbohydrate) $46.21 \%$.

Cal. Gross energy as 5.64, 9.44 and $4.11 \mathrm{Kcal} / \mathrm{g}$ for Protein, lipid, and Nitrogen free extract respectively.

Table 2 shows the essential amino acids which are affected by processing methods. Fermentation method significantly increased the essential amino acids compositions when compared with the raw.

Table 3 shows that processing methods (soaked and fermented) increase the vitamins compositions of $C$. ensiformis seed meal when compared with the raw seed.
Table 4 shows a decreased in the fatty acids compositions in toasted, soaked and fermented methods when compared to the control (raw), while boiled method had the highest compositions.

\section{Discussion}

The crude protein content of raw Canavalia ensiformis seeds reported in this study was found to be higher when compared to an earlier report of Doss et al. [12] on Canavalia ensiformis [14]. However, a significantly higher protein content of processed C. ensiformis seed meal were recorded in this study and agree with the results of Okomoda et al. [9] for C. ensiformis, [15] red kidney bean, but disagreed with Emenike HI, et al [16] who fed jack bean to grower pigs and reported decreased in protein content of different processed seed meals as a result of some nitrogenous substances in the raw beans been solubilized and removed. Rajeev and Karim [17] reported that protein content varied for C. gladiata, but agreed with the result of this work. Alagbaoso et al. [18] reported a higher value for raw Canavalia plagiosperm when compared to this study. The lipid content of $C$. ensiformis from this

\begin{tabular}{|c|c|c|c|c|c|}
\hline & Raw & Boiled & Toasted & Soaked & Fermented \\
\hline Protein \% & $30.32 \pm 0.0^{d}$ & $32.42 \pm 0.01^{c}$ & $35.23 \pm 0.01^{\mathrm{a}}$ & $36.60 \pm 0.00^{\mathrm{a}}$ & $34.73 \pm 0.01^{b}$ \\
\hline Lipid \% & $8.25 \pm 0.00^{b}$ & $8.16 \pm 0.01^{b}$ & $5.85 \pm 0.00^{c}$ & $8.73 \pm 0.01^{\mathrm{b}}$ & $9.23 \pm 0.01^{\mathrm{a}}$ \\
\hline Fibre $\%$ & $4.21 \pm 0.01^{\mathrm{b}}$ & $3.57 \pm 0.01^{\mathrm{b}}$ & $6.35 \pm 0.00^{\mathrm{a}}$ & $4.23 \pm 0.01^{\mathrm{b}}$ & $3.25 \pm 0.01^{b}$ \\
\hline Ash \% & $3.50 \pm 0.00^{b}$ & $3.85 \pm 0.00^{b}$ & $5.32 \pm 0.01^{\mathrm{a}}$ & $3.75 \pm 0.00^{b}$ & $3.60 \pm 0.00^{b}$ \\
\hline Nitrogen free extract $\%$ & $46.21 \pm 0.04^{a}$ & $44.4 \pm 0.04^{\mathrm{b}}$ & $40.40 \pm 0.01^{c}$ & $38.79 \pm 0.02^{\mathrm{c}}$ & $41.68 \pm 0.02^{c}$ \\
\hline Dry Matter \% & $92.49^{b}$ & $92.4^{\mathrm{b}}$ & $93.15^{\mathrm{a}}$ & $92.1^{b}$ & $92.49^{b}$ \\
\hline Calculated Gross Energy (Kcal/g) & $431.3^{a}$ & $434.61^{a}$ & $412.64^{a}$ & $439.78^{a}$ & $445.89^{a}$ \\
\hline $\mathrm{Ca}(\mathrm{g} / 100 \mathrm{~g})$ & $0.312 \pm 0.01^{\mathrm{a}}$ & $0.265 \pm 0.01^{\mathrm{b}}$ & $0.385 \pm 0.01^{a}$ & $0.304 \pm 0.01^{\mathrm{a}}$ & $0.415 \pm 0.02^{\mathrm{a}}$ \\
\hline $\mathrm{Fe}(\mathrm{g} / 100 \mathrm{~g})$ & $0.008 \pm 0.01^{\mathrm{b}}$ & $0.009 \pm 0.00^{b}$ & $0.011 \pm 0.01^{\mathrm{a}}$ & $0.010 \pm 0.01^{\mathrm{a}}$ & $0.011 \pm 0.01^{\mathrm{a}}$ \\
\hline $\mathrm{Mg}(\mathrm{g} / 100 \mathrm{~g})$ & $0.128 \pm 0.01^{d}$ & $0.154 \pm 0.01^{b}$ & $0.182 \pm 0.01^{a}$ & $0.132 \pm 0.02^{\mathrm{c}}$ & $0.155 \pm 0.00^{b}$ \\
\hline $\mathrm{Na}(\mathrm{g} / 100 \mathrm{~g})$ & $0.284 \pm 0.01^{\mathrm{b}}$ & $0.266 \pm 0.01^{\mathrm{b}}$ & $0.311 \pm 0.01^{\mathrm{a}}$ & $0.298 \pm 0.01^{\mathrm{b}}$ & $0.336 \pm 0.01^{a}$ \\
\hline $\mathrm{K}(\mathrm{g} / 100 \mathrm{~g})$ & $1.394 \pm 0.02^{\mathrm{a}}$ & $0.986 \pm 0.01^{b}$ & $1.724 \pm 0.01^{\mathrm{a}}$ & $1.452 \pm 0.01^{\mathrm{a}}$ & $1.694 \pm 0.02^{\mathrm{a}}$ \\
\hline$P(g / 100 \mathrm{~g})$ & $0.185 \pm 0.01^{\mathrm{b}}$ & $0.196 \pm 0.02^{b}$ & $0.253 \pm 0.01^{\mathrm{a}}$ & $0.192 \pm 0.01^{\mathrm{b}}$ & $0.226 \pm 0.00^{\mathrm{a}}$ \\
\hline
\end{tabular}

Table 1: Effect of processing methods on proximate and mineral compositions of Canavalia ensiformis seed meals.

\begin{tabular}{|c|c|c|c|c|c|}
\hline & Raw & Boiled & Toasted & Soaked & Fermented \\
\hline Arginine & $3.81 \pm 0.01^{b}$ & $4.01 \pm 0.01^{b}$ & $5.32 \pm 0.01^{\mathrm{a}}$ & $3.83 \pm 0.01^{b}$ & $5.72 \pm 0.01^{a}$ \\
\hline Histidine & $1.76 \pm 0.01^{\mathrm{b}}$ & $1.92 \pm 0.02^{\mathrm{b}}$ & $2.23 \pm 0.01^{\mathrm{a}}$ & $1.85 \pm 0.01^{b}$ & $3.09 \pm 0.01^{a}$ \\
\hline Isoleucine & $2.94 \pm 0.01^{b}$ & $3.11 \pm 0.01^{a}$ & $2.76 \pm 0.01^{b}$ & $2.87 \pm 0.01^{b}$ & $3.05 \pm 0.00^{a}$ \\
\hline Leucine & $6.53 \pm 0.01^{c}$ & $7.62 \pm 0.02^{b}$ & $8.36 \pm 0.01^{b}$ & $6.78 \pm 0.01^{c}$ & $9.01 \pm 0.01^{\mathrm{a}}$ \\
\hline Lysine & $3.23 \pm 0.01^{b}$ & $3.41 \pm 0.01^{\mathrm{b}}$ & $3.64 \pm 0.01^{\mathrm{b}}$ & $3.26 \pm 0.01^{\mathrm{b}}$ & $4.73 \pm 0.01^{a}$ \\
\hline Methionine & $0.81 \pm 0.01^{b}$ & $0.91 \pm 0.01^{b}$ & $0.88 \pm 0.01^{b}$ & $0.82 \pm 0.01^{\mathrm{b}}$ & $2.12 \pm 0.01^{a}$ \\
\hline Phenylalanine & $3.76 \pm 0.01^{\mathrm{b}}$ & $4.02 \pm 0.02^{\mathrm{b}}$ & $9.34 \pm 0.01^{a}$ & $3.84 \pm 0.01^{\mathrm{b}}$ & $10.23 \pm 0.0^{a}$ \\
\hline Threonine & $1.91 \pm 0.01^{c}$ & $1.21 \pm 1.40^{c}$ & $2.11 \pm 0.01^{b}$ & $1.96 \pm 0.01^{c}$ & $3.43 \pm 0.01^{a}$ \\
\hline Tryptophan & $2.89 \pm 0.01^{d}$ & $3.01 \pm 0.01^{c}$ & $4.02 \pm 0.01^{b}$ & $2.97 \pm 0.01^{d}$ & $5.01 \pm 0.01^{a}$ \\
\hline Valine & $3.98 \pm 0.00^{d}$ & $4.11 \pm 0.01^{c}$ & $5.32 \pm 0.01^{\mathrm{b}}$ & $3.98 \pm 0.01^{\mathrm{d}}$ & $6.08 \pm 0.01^{a}$ \\
\hline
\end{tabular}

Table 2: Effect of processing methods on essential amino acid compositions of Canavalia ensiformis seed (g/16N dry weight basis).

\begin{tabular}{|c|c|c|c|c|c|}
\hline & Raw & Boiled & Toasted & Soaked & Fermented \\
\hline $\mathrm{A}(\mathrm{IU} / 100 \mathrm{~g})$ & $5243.54 \pm 0.02^{b}$ & $3751.26 \pm 0.01^{\mathrm{c}}$ & $1425.32 \pm 0.0^{d}$ & $5743.65 \pm 0.02^{b}$ & $6124.56 \pm 0.01^{a}$ \\
\hline $\mathrm{B} 1(\mathrm{mg} / 100 \mathrm{~g})$ & $0.26 \pm 0.01^{b}$ & $0.22 \pm 0.00^{b}$ & $0.15 \pm 0.01^{c}$ & $0.27 \pm 0.01^{b}$ & $0.32 \pm 0.01^{a}$ \\
\hline B3 $(\mathrm{mg} / 100 \mathrm{~g})$ & $0.17 \pm 0.01^{c}$ & $0.14 \pm 0.01^{d}$ & $0.06 \pm 0.00^{e}$ & $0.19 \pm 0.01^{b}$ & $0.21 \pm 0.00^{\mathrm{a}}$ \\
\hline $\mathrm{B} 6(\mathrm{mg} / 100 \mathrm{~g})$ & $0.14 \pm 0.00^{c}$ & $0.08 \pm 0.00^{d}$ & $0.03 \pm 0.01^{\mathrm{e}}$ & $0.16 \pm 0.00^{b}$ & $0.19 \pm 0.01^{\mathrm{a}}$ \\
\hline $\mathrm{C}(\mathrm{mg} / 100 \mathrm{~g})$ & $18.36 \pm 0.01^{c}$ & $15.35 \pm 0.01^{d}$ & $7.54 \pm 0.02^{\mathrm{e}}$ & $20.42 \pm 0.01^{b}$ & $25.65 \pm 0.00^{\mathrm{a}}$ \\
\hline $\mathrm{D}(\mathrm{mg} / 100 \mathrm{~g})$ & $0.36 \pm 0.01^{d}$ & $0.39 \pm 0.01^{c}$ & $0.45 \pm 0.01^{b}$ & $0.36 \pm 0.01^{d}$ & $0.53 \pm 0.01^{a}$ \\
\hline
\end{tabular}

Table 3: Effect of processing methods on vitamin compositions of Canavalia ensiformis seed meals. 


\begin{tabular}{|c|c|c|c|c|c|}
\hline & Raw & Boiled & Toasted & Soaked & Fermented \\
\hline C10:0 (Capric) & $0.0030 \pm 0.01^{\mathrm{b}}$ & $0.0035 \pm 0.01^{\mathrm{a}}$ & $0.0020 \pm 0.00^{c}$ & $0.0030 \pm 0.01^{\mathrm{b}}$ & $0.0020 \pm 0.01^{\mathrm{c}}$ \\
\hline C12:0 (Lauric) & $0.0040 \pm 0.01^{\mathrm{b}}$ & $0.0050 \pm 0.01^{a}$ & $0.0036 \pm 0.01^{c}$ & $0.0040 \pm 0.01^{b}$ & $0.0030 \pm 0.01^{\mathrm{d}}$ \\
\hline C14:0 (Myristic) & $0.0050 \pm 2.10^{\mathrm{b}}$ & $0.0060 \pm 0.01^{a}$ & $0.0040 \pm 0.01^{c}$ & $0.0060 \mathrm{t} \pm 0.01^{\mathrm{a}}$ & $0.0050 \pm 0.01^{\mathrm{b}}$ \\
\hline C16:0 (Palmitic) & $0.022 \pm 0.01^{\mathrm{b}}$ & $0.023 \pm 0.01^{\mathrm{a}}$ & $0.015 \pm 0.01^{d}$ & $0.022 \pm 0.01^{b}$ & $0.017 \pm 0.00^{c}$ \\
\hline C18:0 (Stearic) & $0.018 \pm 0.01^{\mathrm{b}}$ & $0.019 \pm 0.02^{\mathrm{a}}$ & $0.013 \pm 0.02^{d}$ & $0.018 \pm 0.01^{b}$ & $0.015 \pm 0.01^{\mathrm{c}}$ \\
\hline C18:1 (Oleic) & $0.020 \pm 0.01^{\mathrm{b}}$ & $0.021 \pm 0.01^{\mathrm{a}}$ & $0.016 \pm 0.01^{d}$ & $0.020 \pm 0.01^{\mathrm{b}}$ & $0.017 \pm 0.01^{\mathrm{c}}$ \\
\hline C18:2 (Linoleic) & $0.038 \pm 0.01^{a}$ & $0.038 \pm 0.01^{\mathrm{a}}$ & $0.024 \pm 0.01^{c}$ & $0.039 \pm 0.01^{a}$ & $0.027 \pm 0.01^{b}$ \\
\hline C20:0 (Arachidic) & $0.0060 \pm 0.01^{a}$ & $0.0060 \pm 0.01^{a}$ & $0.0030 \pm 0.01^{d}$ & $0.0050 \pm 0.01^{\mathrm{b}}$ & $0.0040 \pm 0.01^{c}$ \\
\hline
\end{tabular}

Table 4: Effect of processing methods on fatty acids compositions of Canavalia ensiformis seed (g/100 g dry weight basis).

study was not in correspondence to that of Tiamiyu LO, et al [19] for C. ensiformis; [12] for C. ensiformis; [9] for C. ensiformis; [16] for C. ensiformis; [14] for C. ensiformis; C. cathartic and C. maritime [20], but agreed with the results of Rajeev and Karim [17] where lipid varied for C. gladiata, C. ensiformis; C. plagiosperm [18]. The result of this work equally indicated that the various processing methods have not exhibited a significant reduction in the proximate composition of $C$. ensiformis seeds, which agrees with the results of [12]. Effiong and Umoren [21] reported that fiber has some physiological effect in the gastrointestinal tract and low fiber in the diet was undesirable as it may cause constipation. The fiber content of $C$. ensiformis seed for raw and processed in this study falls within the acceptable range of $2.7 \%-7.9 \%$ as reported by Eke et al. [22]. The decrease in fiber content of raw $C$. ensiformis seed meal when compared to processed methods boiled and fermented enhanced nutrients, vitamins, minerals and improved fiber digestibility $[23,24]$. Ash represents the mineral matter left after food material is burnt in oxygen [25]. The presence of ash in C. ensiformis indicated that the seed has good mineral content, hence, can serve as a viable tool for nutrients evaluation [26]. The low value of ash in raw $C$. ensiformis may be a result of the effect of antinutrients on the mineral contents of the sample. Alonso et al. and Anigo et al. [27,28] reported that anti-nutrients could interfere with the bioavailability of minerals. Since anti-nutrients are heat liable, processing could have reduced the levels of the anti-nutrients, thereby improving the bioavailability of the minerals as seen in the resultant increase in the ash content and agreed with the work of Audu SS, et al [15]. The Nitrogen-Free Extract (NFE) of the raw C. ensiformis seed meal and that of the processed had a significant difference. The processed had a significant effect on the NFL content and in agreement with the report of [18]. The NFE content of raw Canavalia ensiformis was lower than that of most legumes like Bambara groundnut (65\%), broad bean (56.9\%), chicken peas (60.9\%) and higher than soya beans (32\%), groundnut $(21.0 \%)$ as reported by Okaka [29]. Carbohydrate (NFE) provides energy to the cells in the body, particularly the brain, it is necessary for the maintenance of the plasma level; it spares the body protein from being easily digested and helps to prevent using up. The fairly high carbohydrate content found in Canavalia ensiformis suggested its caloric value [25]. A decrease in nitrogen-free extracts observed after fermentation was in line with Odetokun SM, Abang FB and Bough SH $[23,24,30]$. Carbohydrates including cellulose, pepsin, lignocellulose, and starch are broken down by fermentative micro-organisms thereby reducing the fiber content of such food [31]. The dry matter ranged was in agreement with the result of [19] but differ with that of Doss et al. [12]. The result agreed with the values for scarlet runner bean [32] and Bambara nut [33]. The moisture content of any food is an index of its water activity and is used as a measure of stability and susceptibility to microbial contamination [34], indicating that raw and processed seeds of Canavalia ensiformis can be processed to flour and kept for some time without microbial spoilage and deterioration in quality [18].

The processed method (boiled) in this study had a higher reducing effect on calcium. Minerals are not destroyed by exposure to heat [35] The reduction, in this case, maybe as a result of leaching of minerals into boiling water. This study revealed that seeds of $C$. ensiformis are rich in mineral elements including Calcium, Phosphorus, Potassium, Magnesium, and Iron. These minerals are necessary for cell formation, transmission of nerve impulse, fluid balance and bone formation $[36,37]$. Processing reduced the vitamin content of $C$. ensiformis seed and this agrees with the report of Asogwa and Onweluzo [38]. Vitamins are lost during processing because of their sensitivity to oxidation and leaching into water [39]. Potassium had the highest value, followed by calcium, this agrees with the result of [40]. It then implies that $C$. ensiformis seed meal could serve as a good source of Potassium and Calcium respectively. The balance of ions in the animal tissues is important for cellular fluid, in order to maintain normal osmotic activity [41].

The essential amino acids were not affected by the processing methods in this study, which is in total disagreement with the work of $[9,19]$ that all the essential amino acids reduced significantly with increasing time of hydrothermal processing. Generally, the reduction in the essential amino acids is likely due to denaturation of the amino acids as boiling time increased. Cereal grain-based diets for fish have been reported to be deficient in lysine, leading to growth reduction $[42,43]$. The relatively high concentration of lysine in C. ensiformis seed makes it a potential supplement in cereal-based diets. One of the most important factors that limit large inclusions of conventional and unconventional feedstuffs in the diet of fish is the leucine/isoleucine ratio [44]. The leucine and isoleucine for hydrothermally processed C. ensiformis observed were higher in value but similar in ratio to reported values of fishmeal [45] and in Agama agama meal [46]. Values of sulphur-containing amino acids such as Methionine and Cystine observed for $C$. ensiformis in this study are relatively lower when compared to the work of $[9,19]$.

Fatty acids act as double-edged swords due to their role as major energy source, structural components of cell membranes, precursors for bioactive molecules, regulators of enzyme activities and gene expression on the positive side; ischaemic/reperfusion injury and heart failures on the negative side via the imbalance in their homeostasis as reported by Sathya and Siddhuraju [47]. The result of fatty acid profiles of C. ensiformis in this study agrees with Bhat and Karim [48] and Siddhuraju and Becker [49] who reported that the unsaturated fatty acid contents in some of the Canavalia spp. (C. ensiformis, C. gladiata, C. cathartic) are much higher (70\%-78\%) than in other 
common legumes like a broad bean (63.8\%) and chicken pea (67.1\%). Gupta et al. and Mohan and Janardhanan [50,51] reported that the seed flour of some Canavalia spp. (C. gladiator, C. ensiformis) possesses ample amounts of essential fatty acids like linoleic and linolenic acids, comparable to soybeans. In fact, $C$. gladiata has been recommended to be considered as a potential oilseed due to its rich content of PUFAs [50,52].

\section{Conclusion}

The results of this study revealed that $C$. ensiformis seeds have a good nutritional profile with a high level of protein, lipid, and other nutrients. Among the various common processing methods employed, toasted and fermented methods were found to improve the nutrient contents of the seeds meal.

\section{Acknowledgment}

The authors are highly grateful to the management of the Modibbo Adama University of Technology Yola, for granting me a study fellowship to undertake this research. The authors would also like to thank the analyst of Animal Nutrition laboratory Adamawa State University Mubi for analysis of the samples.

\section{References}

1. Vietmeyer ND (1986) Lesser-known plants of potential use in agriculture and forestry. Science 232: 1379-1384.

2. Doyle JJ (1994) Phylogeny of the legume family: an approach to understanding the origins of nodulation. Annu Rev Ecol Syst 25: 325-349.

3. Kalidass C, Mohan VR (2012) Biochemical composition and nutritional assessment of selected under-utilized food legume of the genus Rhynchosia. Int Food Res J 19: 977-984

4. Perumal S, Klaus B, Harinder PSM (2001) Chemical composition, protein fractionation, essential amino acid potential and antimetabolic constituents of an unconventional legume, Gila bean (Entada phaseoloides Merrill) seed kernel. J Sci Food Agric 82: 192-202.

5. Escudero NL, Zirulnik F, Gomez NN, Mucciarelli SI, Gimenez MS (2006) Influence of a protein concentrate from Amaranthus cruentus seeds on lipid metabolism. Exp Biol Medicine 231: 50-59.

6. Vijayakumari K, Siddhuraju P, Janardhanan K (1997) Chemical composition amino acid content and protein quality of the little-known legume, Bauhinia purpurea (L). J Sci Food Agric 73: 279-286.

7. Bhag M (1992) Biodiversity utilization and conservation in under-utilized plants: Indian perspective. Indian J Plant Genetic Resour 5: 1-12.

8. Famurewa JAV, Raji AO (2005) Parameters affecting milling qualities of undefatted soybeans (Glycine max L. Merill) (1): Selected thermal treatment. Int J Food Eng 1: 1-9.

9. Okomoda VT, Tiamiyu LO, Uma SG (2016) Effects of hydrothermal processing on nutritional value of Canavalia ensiformis and its utilization by Clarias gariepinus (Burchell, 1822) fingerlings. Aquac Report 3: 214-219.

10. Okonkwo JC, Udedibie ABI (1991) Preliminary observations on the yield performance of jackbean (Canavalia ensiformis) and sword bean (Canavalia gladiata) in the Guinea Savanna of Nigeria. 27th Annual Conference of Agricultural Society of Nigeria, Minna, Nigeria.

11. Adebayo AA (1999) Climate in Adamawa State in Maps. Paraclete Publishers Yola, Nigeria.

12. Doss A, Pugalenthi M, Vadivel VG, Subhashini G, Anitha Subash R (2011) Effects of processing technique on the nutritional composition and antinutrients content of under -utilized food legume Canavalia ensiformis L.DC. Int Food Res J 18: 965-970.

13. AOAC (2012) Official Methods of Analysis. Association of Official analytical

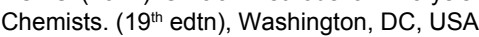

14. Osuigwe DI, Obiekezie Al, Onuoha GC (2005) Some haematological changes in hybrid catfish (Heterobranchus longifilis $\times$ Clarias gariepinus) fed differen dietary levels of raw and boiled jackbean (Canavalia ensiformis) seed meal. Afr J Biotechnol 4: 1017-1021.
15. Audu SS, Aremu MO (2011) Effect of Processing on Chemical Composition of Red Kidney Bean (Phaseolus vulgaris L.) Flour. Pakistan J Nutr 10: 1069-1075.

16. Emenike HI, Udedibie ABI, Emenalom OO (2016) Effects of differently processed Jack bean (Canavalia ensiformis) meals on the performance of grower pigs. British J Appl Sci Technol 13: 1-8.

17. Rajeev B, Karim AA (2009) Exploring the nutritional potential of wild and underutilized legumes. Food Sci Food Safety 8: 305-331.

18. Alagbaoso SO, Nwosu JN, Njoku NE, Ojukwu M, Okafor DC, et al. (2015) Growth performance and haematology of albino rats fed varying inclusions of autoclaved canavalia plagiosperma piper seed meal based-diets. Am J Food Nutr 5: 35-48.

19. Tiamiyu LO, Okomoda VT, Akpa PO (2016) Nutritional profile of toasted Canavalia ensiformis seed and its potential as partially replacement for soybean in the diet of Clarias gariepinus. Braz J Aqua Sci Technol 20.

20. Arun AA, Sridhar KR, Raviraja NS, Schmidt E, Jung K (2004) Nutritional and anti-nutritional Components of Canavalia spp. Seeds from the west coast sand dunes of India. Plant Food Hum Nutr 58: 1-13.

21. Effiong $O O$ and Umoren UE (2011) Effect of Multiprocessing techniques on the chemical composition of Horse Eye bean (Mucuna urens). Asian J Anim Sci 5: $340-348$.

22. Eke CNU, Asoegwu SN, Nwandikom GI (2008) Physical Properties of Jack bean (Canavalia ensiformis). Agricultural Engineering International: The CIGRE Journal.

23. Odetokun SM (2000) Effect of fermentation on some physio-chemical properties, antinutrients and in-vitro multi-enzymes digestibility of selected legumes. Federal University of Technology, Akure, Nigeria.

24. Abang FB, Shittu HA (2015) Effect of fermentation on the chemical composition of peeled taro cocoyam meal (Colocasia Esculenta Var Esculenta). IOSR J Agric Vet Sci 8: 31 -33.

25. Enwereuzoh RO, Okafor DC, Uzoukwu AE, Ukanwoke MO, Nwakaudu AA et al. (2015) Flavour extraction from Monodora myristica and Tetrapleura tetraptera and production of flavoured popcorn from the extract. Europe $\mathrm{J}$ Food Sci Technol 3: 1-17.

26. Lienel HH (2002) Ash analysis in introduction to chemical analysis of foods, Nielsen. CBS PUBLISHERS, New Delhi.

27. Alonso R, Rubio LA, Muzquiz M, Marzo F (2001) The effect of extrusion cooking on mineral bioavailability in pea and kidney bean seed meals. Anim Feed Sci Technol 94: 1-13.

28. Anigo IA, Ameh DA, Ibrahim S, Danbauchi SS (2009) Nutrient composition of commonly used complimentary foods in North Western Nigeria. Afr J Biotechnol 8: 4211-4216.

29. Okaka JC (1997) Cereals and legume storage and processing technology Ogui-Enugu, Nigeria: Data and Micro System Publishers.

30. Bough SH, Azam-Ali SN (1992) The effect of soil moisture on the reproductive performance of Coturnix breeder hens. Poult Sci 51: 1662-1669.

31. Raimbault AO, Tewe OO (2001) Protein enrichment of sweet potato by solid substrate fermentation using for monoculture fungi. Niger J Biotechnol 9: 1 - 4

32. Aremu MO, Olaofe O, Basu SK, Abdulazeeez G, Acarya SN (2010) Processed cranberry bean (Phaseoluscoccineus) seed flour for African diet. Can J Plant Sci 90: 719-728.

33. Olaofe O, Famurewa FA, Ekuagber AO (2010) Chemical and functional properties of kidney bean seed (Phaseolus vulgaris L) flour. Int $\mathrm{J}$ Chem Sci 3: $51-69$.

34. Aruah BC, Uguru MI, Oyiga BC (2012) Genetic variability and interrelationship among some Nigerian pumpkin accessions (Curcurbitassp). Plant Breed Int $J$ 6: $34-41$

35. Amarowiez R, Carle R, Dongowski G, Durazzo A, Galensa R, et al. (2009) Influence of postharvest processing and storage on the content of phenolic acids and flavonoids in foods. Mol Nutr Food Res 53: S151-S183.

36. Ezeagu IE, Ologhobo AD (1995) Proximate composition of unfamiliar plant seeds in Nigeria-A short report. Pol J Food Nutr Sci 4: 79-83.

37. Nwafor FI, Egonu SN, Nweze NO, Ohabuenyi SN (2017) Effect of processing 
Citation: Michael KG, Sogbesan OA, Onyia LU (2018) Effect of Processing Methods on the Nutritional Value of Canavalia ensiformis Jack Bean Seed Meal. J Food Process Technol 9: 766. doi: 10.4172/2157-7110.1000766

methods on the nutritional values and anti-nutritive factors of Adenanthera pavonina L. (Fabaceae) seeds. Afr J Biotechnol 16: 106-112.

38. Asogwa IS, Onweluzo JC (2010) Effects of processing methods on the chemical composition of flour, moinmoin and akara from Mucuna pruriens. J Trop Agric Food Environ Ext 9: 200-208.

39. Aremu MO, Olaofe O, Basu SK, Abdulazeeez G, Acarya SN (2010) Processed Cranberry bean (Phaseoluscoccineus) seed flour for African diet. Can J Plant Sci 90: 719-728.

40. Davey MW, Montagu MV, Inze D, Sanmartin M, Kanellis A, et al. (2000) Plant L-ascorbic acid: chemistry, function, metabolism, bioavailability and effects of processing. J Sci Food Agric 80: 825-860.

41. Anhwange BA, Ajibola VO, Oniye SJ (2004) Chemical Studies of the Seeds of Moringa oleifera (Lam) and Detarium microcarpum (Guill and Sperr). J Bio Sci 4: 711-715

42. National Research Council (1993) Nutrient Requirements of fish. National Academy Press, Washington DC, USA.

43. Mostafa MM, Rahma EH, Redy AH (1987) Chemical and nutritional changes in soybean during germination. Food Chem 23: 257-275.

44. Cheng ZJ, Hardy RW, Usry JL (2003) Plant protein ingredients with lysine supplementation reduce dietary protein level in rainbow trout (Oncorhynchus mykiss) diets, and reduce ammonia, nitrogen and soluble phosphorus excretion. Aquaculture 218: 553-565.
45. Tiamiyu LO, Okomoda VT, Iber B (2013) Growth response of Clarias gariepinus fingerlings fed diet substituted groundnut cake meal and cotton seed meal. Livestock Res Rural Dev.

46. National Research Council (1977) Nutritional requirement of warm water fishes. National Academy of Science, Washington DC.

47. Tiamiy LO, Solomon SG, Satimehin SPD (2014) Growth performance of Clarias gariepinus Fingerlings fed varying levels of the seed of Luffa cylindrica meal in outdoor Hapas. Octa J Biosci 2: 8-12.

48. Sathya A, Siddhuraju P (2015) Effect of processing methods on compositional evaluation of underutilized legume, Parkia roxburghii G. Don (yongchak) seeds. J Food Sci Technol 52: 6157-6169.

49. Bhat R, Karim AA (2009) Exploring the nutritional potential of wild and underutilized legumes. Compr Rev Food Sci Food Saf 8: 305-331.

50. Siddhuraju P, Becker K (2001) Species/variety differences in biochemical composition and nutritional value of Indian tribal legumes of the genus Canavalia. Nahrung 45: 224-233.

51. Gupta R, Rauf A, Ahmad MA, Ahmad F, Osman SM (1983) Chemical screening of seed oils. J Oil Technol Assoc India 15: 6-7.

52. Mohan VR, Janardhanan K (1994) The biochemical composition and nutrien assessment of less known pulses of the genus Canavalia. Int J Food Sci Nutr 45: $255-262$ 